\title{
PROGRESS OF INDUSTRIAL RESEARCH IN BRITAIN
}

$R^{R}$ ESEARCH for Industry, 1964*, the report of the Industrial Grants Committes of the Department of Scientific and Industrial Resoarch, covers the first 3 months of 1965 in addition to 1964, and this year comes from the Ministry of Technology. It includes progress reports from thirteen research associations, whose grants came up for renewal in 1964, together with articles by Dr. N. F. Astbury on "Research Associations, Education and Industrial Training", and by S. S. Carlisle on "Automation Research and Development in Research Associations". It also contains the usual directory information on the research associations. The total annual income is now $£ 11 \cdot 3$ million with $£ 2.6$ million in grants from the Department of Scientific and Industrial Research, compared with $£ 170,000$ and $£ 61,000$ respectively in 1927 .

At its final meeting the Committee considered an application for a grant from the Machine Tool Industry Research Association, which is growing at a satisfactory rate and doing a most important job. The Committee considers that the Association should be given every possible encouragement and recommends a continuation of the generous terms of this grant.

On grants policy generally, the Committee now favours a revenue grant, usually for 5 years, as a fixed percentage of grant-earning subscriptions over a range of industrial income, and in 1964 seventeen of its eighteen recommendations took this form.

Two ear-marked grants recommended during the year were $£ 34,325$ over 3 years, to the Water Research Association to investigate the application of de-salting brackish and sea-waters to British water supply, and up to $£ 39,865$, also over 3 years, to enable the Ceramic, Steel Castings and Cast Iron Research Associations to extend their investigations into measuring dust in the working environments of their industries.

A grant announced in 1963, to the Cotton, Silk and Manmade Fibres Research Association, has been increased to $£ 74,600$ over 3 years to study new methods of spinning. The British Baking Research Association is also to receive an ear-marked grant of $£ 26,800$ towards the cost of a 5 -year study of the staling of bread; the Electrical Research Association up to $£ 17,400$ for basic research into electrical conduction in dielectries; and the Timber Research and Development Association half of the $£ 45,000$ cost of an operational research study of timber handling over $2 \cdot 5$ years, especially of the feasibility of importing timber into Britain in packages of standard size. A 50 per cent grant not exceeding $£ 38,000$ was awarded to the Rubbor and Plastics Research Association for an investigation of the possibility of controlling a rubber factory engaged in batch production by a computer, programmed to plan the production in the most efficient way, with regard to utilization of plant and materials. A 75 per cent grant, not excoeding $£ 54,300$, is to be awarded to the British Industrial Biological Research Association for research into the injection method of testing food abstracts.

The British Cast Iron Rescarch Association carriod out an extensive programme of experimental work to obtain more basic data on cupola melting and to develop improvod techniques of molting and metal treatment; much effort was devoted to the development and application of non-destructive testing techniques for iron castings.

One outcome of the Electrical Research Association's work on high-temperature plasmas has been a novel form of plasma furnace which can spheroidize highly refractory particles and may have other important applications. During the past 18 months, the British Hat and Allied

* Ministry of Technology. Research for Industry, 1964. (A Report on work done by industrial research associations in the Government seheme.) Pp. ii
$+72+20$ plates. (London: H.M.S.O., 1965.) 8s.
Feltmakers' Association has discovered a new method of preparing hatter's fur (this has already reached the stage of production), and also a method of dyeing felt bodies, using the faster classes of dye without recourse to preneutralization. In the work undertaken by the Furniture Industries Research Association on comfort of chairs, all existing anthropometric data relating to sitting were surveyed. Furthermore, research is now proceeding on the uso of resilient urethane foams for upholstered furniture, on the structural design of chair frames and the joints used in them, and on the avoidance of lacquer waste in spraying furniture.

The inter-firm comparison of the performances of furnaces melting container glasses, which the British Glass Industry Research Association started in 1962, has proved so successful that all British manufacturers are now included, as are more than half the American container glass industry and almost all the Western European firms making glass containers. Considerable contributions have been made towards explaining the basic mechanisms of the corrosion of refractory materials by molten glass and the materials carried in the waste gases, as well as towards the more accurate prediction of the service life of refractories and ways of assessing the effects of changes in refractories on the economics of furnace operation. The Association is also attempting to fill the gap in available knowledge of the process of forming commercial glass by a fundamental investigation, using computer techniques, of the various parameters involved and by direct measurements on the forming machines in the works of members.

The Hosiery and Allied Trades Research Association's basic studies of the factors involved in producing baulked nylon yarns have led to the development and widespread application of two control tests; the crimp rigidity test and the equivalent steam-setting temperature test. A lateral stretch device has been developed for checking the width-wise extension of ladies' hose, as has a qualitycontrol gauge for latch-and bearded-needle fiat machines which enables the number of loops in a fixed length of yarn to be determined.

The British Launderers' Research Association has reduced the amount of water required for rinsing without adversely affecting the quality of the work produced. Investigations are proceeding into the application of heat-transfer fluids other than steam to the drying and ironing equipment of laundries, with a view to increasing productivity by the use of higher operating temperatures. Two effective procedures have been developed for disinfecting wool blankets - one involving boiling and the other the use of chemical disinfectants.

The British Leather Manufacturers' Research Association has completed its investigation of the drying rates of different kinds of leather in air at various temperatures, humidities and rates of flow and normal pressure, as well as a 5-ycar research project on the resistance of leather to heat, moisture and perspiration.

An important achievement has been the introduction of 'Procion' dyes to the leather industry and development of a 'Procion' resist. Addition of benzyl and isopropyl alcohols increased the range of dyes that can be used in spray-dyeing leather and also increased their penetration.

Recent activities of the British Scientific Instrument Research Association in developing industrial measurement techniques have included tho dovelopment of an emissivity-compensated service pyrometer, which is now undergoing trials in several industries, and a nucleonic gas-flow meter and density gauge. Research is being carried out on techniques of automatic surface inspection, and the development of more efficient detecting screens 
for high-energy X-ray fluoroscopy. Work in thinfilm technology has been considerably developed and has concentrated on the electrical application of thin films.

The British Steel Castings Research Association is developing special methods of applying materials and has shown that chromite sand is a valuable substitute for zircon sand. Tests have shown that, using this method, austenitic manganese steels can be produced from scrap more economically than by previous methods. Trials are at present proceeding to assess the efficiency of deoxidizers which could lead to the production of superior steels at a lower economic cost.

Research in plant engineering has included the wet reclamation of clay-bonded sand, and investigations of the efficiency and rate of cleaning of steel-castings have shown how shot and other abrasives can be used more efficiently and can provide a method for removing very hard and tenacious cores. In welding technology, the use of a gas shield around a welding are has proved of great value during the past few years in solving such problems as the welding of thin aluminium alloy sheets, the positional welding of steel and the welding of a whole range of alloys in which metal transfer in the ordinary gas-shielded welding is difficult and erratic. The British Welding
Research Association has also overcome difficulties due to resistance in spot-welding by developing a monitoring device which gives a reliable indication of the occurrence of defective welds during the welding operation. Progress already achieved in welding high-tensile steels made it possible for welding to be used in constructing the Forth Bridge, and this is estimated to have cut construction costs by $£ 1$ million. A completely new method has been developed for the hydrogen analysis of metals, and methods and equipment developed by the Association to test very large steel plates are now used in every industrial country.

The Welwyn Hall Research Association was formed on October 1, 1964, by the amalgamation of the Whiting and Industrial Powders Research Council and the Chalk, Lime and Industries Research Association. During the past 5 years the Council has advanced over a broad front, rather than in particular fields. The latter Research Association, however, has investigated particularly the problems of the heat balance of shaft lime-kilns and their operation, and this has led to a better understanding of the factors affecting fuel efficiency. An investigation of the factors affecting the quality of calcium silicate bricks has also been undertaken, which has led to the manufacture of stronger bricks with greater dimensional stability.

\section{SPACE AGE SCIENCE AND TECHNOLOGY}

$\mathrm{A}^{\mathrm{s}}$ PART from what the Earl of Bessborough said in his opening speech, the debate on space age science and technology in the House of Lords on November 3 is of interest mainly for what Lord Shackleton said about Britain's effort in this field and for what Lord Bowden and Lord Snow, who replied to the debate, said about the organization of our research effort and the choice of priorities. The Earl of Bessborough asked some searching questions about the extent of our effort in space research, with which he was dissatisfied. He did not suggest that this effort was necessarily more important than that concerned with other scientific and technological needs, particularly in the less developed countries. The research effort was considerable, but he was concerned that the overall proportion of our research expenditure in the main fields should be right. Lord Shackleton referred to the brilliant report of the Bondi Committee, but said that it could not be published for security reasons. The original estimate of the cost of the European Launcher Develop. ment Organization was $£ 70$ million, of which our share was 38.8 per cent. When the studies for further programmes were available early next year we should have to consider the estimate very carefully in relation to the technological advantages to be derived from the present and possible future programmes. Concerning satellite communications, he said that the United Kingdom, France and several European countries established in 1963 the Europoan Conference on Satellite Communications and, in the following year, negotiations with the United States, Canada, Australia and Japan led to the drafting of two interim agreements. These covered the establishment of a global satellite system under the Interim Committee on Satellite Communication on which the United States was represented by its Communications Satellite Corporation.

At present there was no alternative to the use of United States launchers and satellites. The Early Bird satellite, which is now in regular service and carries part of our transatlantic telephone service, was commissioned before the agreements were signed. It is expected that we will have a global service and that this will render an economic return in due course, but it will take some time for the system to reach a level of development which will be economic. Satellite Early Bird was primarily an experiment to determine, first, whether a satellite of this type would provide an acceptable telephone service and, secondly, to gain operating experience. The specification for future satellites which has now been drafted aims at an average life of five years, and it is hoped that, in the future, ten years will be achieved. Although the United Kingdom and the European Launcher Development Organization have the range and supporting facilities of Woomera, there are great advantages in equatorial orbits, and some consideration is being given to the possibility of an alternative launching site near the Equator. Work in Government establishments and in industry on the basic satellitetechnology programme has covered design and technological problems relating to satellites, including studies for astronomical satellites and communication satellites and research and development on solar cells, the effect of space environment on electronic components, altitudes sensing, and control systems. Defence Research Estab. lishments had been working on methods of space communication without using man-made satellites. Notable advances in weather forecasting had already been made through the use of space techniques. In the current year the level of expenditure in this field looked like being about $£ 20$ million.

In a maiden speech, Lord Ironside referred to the European Space Research Organization Convention, which came into force on March 23, 1964, in which ten countries were now participating, Austria and Norway having dropped out. Much expenditure was at present capital, but the emphasis was slowly shifting to project work. Contributions to the European Space Research Organization, at present something like $£ 7$ million, were expected to approach $£ 20$ million a year in two or three years' time. Lord Ironside said he thought the return to this country would come first through the return of technologists, after service abroad, and through the placing of contracts in this country by the Organization, which would strengthen United Kingdom industry in space technology and stimulate advances in related technologies, such as telecommunications, vacuum techniques and cryogenics. Lord Bowden's speech was essentially concerned with the organization of civil research and the choice of priorities, and he claimed that the new Council on Science Policy constituted a notable advance. He asked whether the Government proposed to publish Prof. 